\title{
Beta-cell function and human islet transplantation: can we improve?
}

\author{
Jennifer Chen ${ }^{1}$ and Jenny E Gunton ${ }^{1,2,3,4}$ \\ 1The Westmead Institute for Medical Research, The University of Sydney Westmead Hospital, New South Wales, Australia \\ 2Department of Endocrinology and Diabetes, Westmead Hospital, Sydney, New South Wales, Australia \\ ${ }^{3}$ Garvan Institute of Medical Research, Sydney, New South Wales, Australia \\ ${ }^{4}$ St Vincent's Clinical School, University of New South Wales, Sydney, New South Wales, Australia
}

Correspondence should be addressed to J E Gunton: jenny.gunton@sydney.edu.au

\begin{abstract}
Islet transplantation, a therapeutic option to treat type 1 diabetes, is not yet as successful as whole-pancreas transplantation as a treatment for diabetes. Mouse models are commonly used for islet research. However, it is clear disparities exist between islet transplantation outcomes in mice and humans. Given the shortage of transplant-grade islets, it is crucial that we further our understanding of factors that determine long-term islet survival and function post-transplantation. In turn, this may lead to new therapeutic targets and strategies that will improve transplant outcomes. Here, we summarise the current landscape in clinical transplantation, highlight underlying similarities and differences between mouse and human islets, and review interventions that are being considered to create a new pool of $\beta$-cells for clinical application.
\end{abstract}

$\begin{aligned} & \text { Key Words } \\ \text { - } & \beta \text {-cells } \\ \text { - } & \text { islet transplantation } \\ \text { - } & \text { human } \\ \text { - } & \text { diabetes }\end{aligned}$

\section{Introduction}

The pancreas lies posterior to the stomach, extending from the spleen to the duodenum. It contains cells which perform exocrine and endocrine functions. Endocrine cells are found in clusters called the islets of Langerhans or pancreatic islets. Although they consist of only $1-2 \%$ of the adult pancreas, islets are critical for regulating glucose homeostasis. The hormone insulin is secreted solely by islet $\beta$-cells. When blood glucose levels rise, insulin is released. Diabetes occurs when $\beta$-cell dysfunction or loss leads to an inability to release enough insulin to control glucose. Other islet endocrine cell types include glucagonsecreting $\alpha$-cells, $\delta$-, pancreatic polypeptide (PP), and $\varepsilon$-cells.

Insulin reduces blood glucose by initiating peripheral glucose uptake particularly in muscle and adipose tissue, and repressing glucagon activity. Glucose transporters GLUT1, GLUT2 and GLUT3 (predominantly GLUT1) facilitate glucose uptake in human $\beta$-cells. In mouse $\beta$-cells,
GLUT2 is the primary glucose transporter. Glucokinase phosphorylates glucose into glucose-6-phosphate, preventing the diffusion of glucose back into circulation; it is the major $\beta$-cell glucose-sensor for both organisms (De Vos et al. 1995). Glucose-6-phosphate is catabolised through glycolysis and the Kreb's cycle to produce ATP from adenosine diphosphate (ADP). Increased cytoplasmic ATP:ADP ratio is detected by ATP-sensing potassium channels which then close, depolarising the cell membrane. This opens voltage-gated $\mathrm{Ca}^{2+}$ channels, triggering insulin granule exocytosis.

The key function of differentiated $\beta$-cells is glucosestimulated insulin secretion (GSIS). GSIS normally occurs over two phases. First-phase GSIS occurs rapidly, by definition, within $10 \mathrm{~min}$ of a glucose stimulus. This is thought to be mediated by the release of mature secretory insulin granules already close or docked to the $\beta$-cell plasma membrane. Then, there is a gradual second 
phase, beginning 10-20 min after glucose stimulus. In humans, the activating threshold for GSIS is $3 \mathrm{mmol} / \mathrm{L}$ glucose in the 'lowest' glucose-sensing cells, with a range of response thresholds recruiting more $\beta$-cells as glucose increases (Henquin et al. 2006). In rodents, the threshold is $5 \mathrm{mmol} / \mathrm{L}$.

In type 1 (T1D) diabetes, $\beta$-cells are destroyed by the immune system (Atkinson \& Eisenbarth 2001, Sherry et al. 2005), and in type 2 (T2D) diabetes, they have impaired function (van Haeften 2002, Gunton et al. 2005). In the early stages of T1D, there is preferential $\beta$-cell loss but later there is often 'by-stander' damage and loss of the other islet cell types as a consequence of the immune attack. In human T2D, there is differential $\beta$-cell loss, and insulin degranulation identified using electron microscopy.

Insulin immunohistochemistry is the most commonly used technique for labelling $\beta$-cells. However, negative immunostaining may be due to severe degranulation rather than loss of $\beta$-cell mass (Butler et al. 2003, Marselli et al. 2014, Cinti et al. 2016). However, some T2D patients have comparable granule density in nonhormoneexpressing endocrine cells to nondiabetic controls which questions the degranulation model. The presence of these nonhormone-expressing endocrine cells may be attributed to $\beta$-cell dedifferentiation or formation of immature new endocrine cells (Butler et al. 2016). Supporting reversion to a nonmature state is the elevated expression of gastrin, a foetal pancreas biomarker, found in diabetic mouse $\beta$-cells and T2D human $\beta$ - and $\delta$-cells (Dahan et al. 2017).

Islet transplantation is a promising treatment for adults ( $>18$ years) with T1D for a duration of 5 or more years and experiencing severe hypoglycemic unawareness events (Transplantation Society of Australia and New Zealand). The procedure aims to restore insulin independence, defined by the Collaborative Islet Transplant Registry (CITR) as the absence of the need for exogenous insulin administration for more than 14 consecutive days. However, clinical application is hampered by donor availability, and in the early transplant patients, poor rates of long-term graft function. Approximately half of all transplant recipients remained insulin independent 12 months after the last islet infusion; most experienced a gradual decline in function. While an overall reduction of exogenous insulin requirement and improved glucose handling was observed, only $16 \%$ of recipients were insulin independent across all follow-up times. However, importantly, severe hypoglycemia was eliminated in $90 \%$ of recipients over 5 years of follow-up. Variables affecting graft outcomes included recipient age, induction and maintenance immunosuppression, and total islet equivalents (IEQs) infused (CITR). Long-term graft function is hindered by numerous factors including the toxicologic profile of immunosuppressives, limited graft $\beta$-cell proliferation, and substantial islet necrosis and apoptosis (Shapiro et al. 2017).

Research efforts to study the human endocrine pancreas is limited by lack of access to tissue in living people, technical challenges in measuring $\beta$-cell function, and inability to measure $\beta$-cell mass. Few studies have attempted to take pancreas tissue from a living person: two Japanese studies described pancreatic punch biopsies as a safe procedure with minimal complications, but the Diabetes Virus Detection study (DiViD) was discontinued due to a high rate of complications (Imagawa et al. 2001, Krogvold et al. 2014). Thus the safety of obtaining pancreatic biopsies is not clear, and if it is not safe, then it is arguably unethical. Furthermore, islets are not homogenously distributed in the human pancreas, thus a single biopsy may not be representative.

In studying isolated islets, they are obtained only from organ donors. Availability is low, and there are challenges in isolating good quality human islets (Ricordi et al. 2016). In addition, islets de-differentiate soon after isolation in culture, losing their specialised phenotype (Negi et al. 2012, Spijker et al. 2013). Indeed, after 7 days, few islets retain GSIS. Consequently, many studies have looked at characterising islet physiology to further our understanding of mechanisms and pathways that contribute to graft failure post-transplantation (Omori et al. 2016, Cross et al. 2017, Gan et al. 2018). Others have focused on developing strategies to stimulate $\beta$-cell proliferation or providing an alternative source of $\beta$-cells by inducing cell transdifferentiation.

A limitation of human $\beta$-cell lines is that very few display GSIS (Halvorsen et al. 2000, Ravassard et al. 2011). In addition, in vitro models do not encapsulate the complex interactions between physiological systems in whole organisms that can affect graft outcomes. Thus, a commonly used model organism for studying $\beta$-cell function is the laboratory mouse, where advantages include its relative genetic similarity of humans, shorter lifespan and readily manipulable genome.

The drugs alloxan and streptozotocin are used to induce diabetes in mice (Kodama et al. 2005). They are taken up by the cells as glucose analogues and cause free-radical induced DNA damage. However, these drugs are one of the few examples where human islets are more robust than the animal models; human $\beta$-cells are resistant, possibly due to rapid export of the toxins (Yang \& Wright 2002). This feature is useful when testing 
human islet transplantation, as recipient mice can be given diabetes-inducing doses of the $\beta$-cell toxins shortly before transplantation without damaging the human islets (Eizirik et al. 1994, Stokes et al. 2017). Other notable differences between mouse and human islets include the spatial arrangement of endocrine cell types, especially in large human islets, and differences in islet vasculature and autonomous nervous system (ANS) innervation. In this review, we will first provide a brief overview of the current islet transplantation landscape and then discuss the similarities and differences between mouse and human islet biology that could contribute to differential graft success.

\section{Current state of islet transplantation}

Deceased donors are the primary source of human islets for transplantation. In most cases, they are brain-dead but heart beating, although some countries use non-heartbeating donors. Islet isolation yield and success rate is generally higher in heart-beating donors, and obese and younger donors ( $<47$ years) although there are conflicting reports (Matsumoto et al. 2004, Niclauss et al. 2011). Graft function of islets from donors $>40-45$ years old perform worse, possibly due to defects in intracellular ATP production (Ihm et al. 2006, Niclauss et al. 2011).

In humans, restoration of normoglycemia and insulin independence in many patients requires $~ 12,000$ IEQ/kg body weight (Shapiro et al. 2000). This usually is obtained from 2 to 3 donors. Considering the substantial number, it is critical to find strategies to minimise the number of islets that are lost during isolation and posttransplantation (Davalli et al. 1995). In more recent years, increasing numbers of people become insulin independent with islets from 2 , or sometimes only 1 donor. Activation of the recipient's immune response to transplanted islets remains a barrier yet to be completely overcome (Bennet et al. 2000, Barra \& Tse 2018).

The longevity of graft function has clearly progressed since the initial successes with the Edmonton protocol immunosuppression regimen (Brennan et al. 2016). This glucocorticoid-free protocol with low dose tacrolimus (a calcineurin inhibitor (CNI)), sirolimus (a mTOR (mechanistic target of rapamycin, previously called the mammalian target of rapamycin) inhibitor) and an interleukin-2 receptor antagonist (Daclizumab) saw improvements over the modest success initially seen with the drug combinations used for whole organ transplantation. The 'Edmonton protocol' has evolved since then; post-2007 saw a shift towards T-cell depleting agents (e.g. Alemtuzumab, hOKT3y-1-ala-ala) and TNF alpha (TNF $\alpha$ ) inhibitors with or without interleukin-2 receptor-antagonists for immunosuppression induction (CITR). These changes aim to control early inflammatory events that may limit short-term graft survival. Benefits of TNF $\alpha$ antagonists requires T-cell depletion at induction (Froud et al. 2005, Williams et al. 2018).

Similarly, there has been a shift in maintenance immunosuppression therapy away from mTOR inhibitors to a combination of CNI and inosine-5'-monophosphate dehydrogenase (IMPDH) inhibitors (mycophenolate mofetil or mycophenolic acid) between 2007 and 2015 (CITR). The side effect profile of mTOR inhibitors may explain this change, yet pre-treatment with mTOR inhibitors before transplant can enhance insulin sensitivity (Benedini et al. 2018). In line with this, the well-documented adverse outcomes of long-term CNI use has prompted investigation into alternate primary immunosuppressants. CNI-free protocols involving co-stimulation blockade-based agents (Belatacept, Abatacept) or a combination of mTOR and IMPDH inhibitor maintenance have been trialled with up to $40 \%$ of patients retaining insulin independence for at least 3 years (Maffi et al. 2014).

\section{Transplant sites}

It is clear that mouse islets usually provide superior transplant outcomes to human islets, even with comparable or larger mass of human islets (Stokes et al. 2017). Most studies in mouse recipients use the kidney capsule as the graft site as the surgical protocol is relatively easy and gives superior outcomes. However, the human kidney does not readily allow creation of an anatomical space under the capsule to place the islets. In addition, there are valid concerns about potential damage to the kidney in people with diabetes. Moreover, some of the immunosuppressive medications used in islet transplant recipients can cause renal impairment.

The current clinical site for human islet grafts, the portal vein, leads to marked loss of islets in the short term. This is estimated to be over 50\%, and many patients experience 'dumping' shortly after transplantation where they have hypoglycaemia due to release of large quantities of insulin from dying $\beta$-cells. An ideal implantation site would minimise clotting, especially the immediate blood mediated immune reaction (IBMIR), have high blood vessel density for adequate islet blood supply and oxygenation and be readily accessible and safe surgically. 
Notably, Sertoli cells in the testes and parenchymal cells of the eye anterior chamber both possess site-specific immunosuppressive mechanisms to circumvent clotting and IBMIR (Selawry \& Cameron 1993, Griffith et al. 1995). This could act to reduce or eliminate the need for chronic systemic immunosuppression. Sertoli cells have the capacity to induce $\beta$-cell regeneration and augment graft survival in mice (Luca et al. 2010, Li et al. 2013). In the eye, there are a high concentration of autonomic nerves and blood vessels. Moreover, a relatively low number of islets are needed for glycemic control without compromising visual acuity. One syngeneic mouse model found that islets engrafted into the eye were susceptible to immune attack but this may be due to variations in islet preparation and surgical protocol (Mojibian et al. 2013). Establishing the safety and efficacy of this approach is the subject of active clinical trials (NCT02916680, NCT02846571, NCT04198350). We speculate that the clinical acceptability of ocular transplants will vary between patients.

Other alternate engraftment sites being evaluated in preclinical models and early clinical trials include muscle, bone marrow, and omentum (Christoffersson et al. 2010, Stokes et al. 2017, Stice et al. 2018). Revascularisation of islets before transplantation is also being considered to prevent graft loss, although hypervascularisation may facilitate cytokine immune attack (Bowers et al. 2019).

\section{Agents to improve islet viability in culture}

Most centres have adopted variations of the Edmonton protocol for isolating and transplanting human islets. Islets are cultured short-term for quality control studies including assessment of purity, viability, and lack of infection (Hering et al. 2004, Froud et al. 2005, O'Connell et al. 2013). There is some controversy regarding whether culturing islets pre-transplantation results in better islet engraftment outcomes (Noguchi et al. 2012). Nevertheless, the culturing period provides a window where islets may be treated with agents that promote regeneration of vasculature and extracellular matrix (ECM) fractured during isolation, or counteract localised coagulation cascade response. After intraportal islet infusion, islets are exposed to the portal venous oxygen tension, which is relatively hypoxic (Carlsson et al. 2001). Data from a computational oxygen simulation support the hypothesis that the decrease of oxygen tension is a primary cause of central necrosis in cultured islets (Komatsu et al. 2017). To maximise transplantation success, it is important to re-establish oxygenated blood flow post-transplantation either by minimising destruction of the original islet vascular network or stimulating re-vascularisation in the implantation organ (reviewed in (Jansson \& Carlsson 2002)).

The drug deferoxamine is an iron chelator which inhibits degradation of the hypoxia inducible factor $1 \alpha$ (HIF-1 $\alpha$ ) protein. Overnight culturing of human islets in deferoxamine using normal therapeutic concentrations had a protective effect on islets transplanted into mice and led to greater CD31/PECAM1 immunostaining, a biomarker for blood vessels. This suggests there was greater angiogenesis in the human islets, although the study period was limited to 28 days. Islet cell apoptosis was lower in deferoxamine treated islets. Glucose outcomes for human islets transplanted into mice were superior for islets cultured with deferoxamine pre-transplantation (Stokes et al. 2013).

Other studies have focused on reducing the rapid production of monocyte chemoattractant protein-1 (MCP-1/CCL2) and tissue factor. These proteins induce inflammatory and apoptotic responses through the recruitment of clotting factors (Johansson et al. 2005). Nicotinamide, a vitamin B3 isotype (Moberg et al. 2003) has been proposed to treat this. This compound has also been implicated in the prevention of macrophage mediated destruction of rodent islets (Kolb et al. 1990). In a syngeneic islet transplant mouse model, preculturing islets (300 IEQ) in nicotinamide allowed a faster return to normal glucose in addition to prolonging graft survival (Jung et al. 2009). In a mouse model of ischemic injury, increasing NAD (NAD+) levels stimulated neovascularisation and restored vascular density in muscle (Das et al. 2018). Phase 1 clinical trials examining agents which may augment isolated islet survival include the synthetic peptide PKX-001 (NCT03073577), thought to be cytoprotective against immunosuppressant toxicity and BMX-010 (NCT02457858), an antioxidant which has been shown to be efficacious in mouse islet engraftment outcomes.

Another strategy currently being explored to increase islet viability targets the intra-islet and peripheral islet ECM and endothelium that is damaged during enzymatic dissociation of islets. Mesenchymal stem cells (MSC), implicated in tissue repair and maintenance of cellular homeostasis, secrete factors with anti-inflammatory, proangiogenic and regenerative properties (Kuljanin et al. 2019). MSCs can be isolated from many sources such as adipose tissue and bone marrow. Moreover, MSCs isolated from patients with chronic pancreatitis have comparable effectiveness in protecting human islets exposed to 
hypoxia as those isolated from a healthy donor (Wang et al. 2019). Islets precultured with adipose-derived MSCs reversed hyperglycemia in a syngeneic mouse transplant model. Notably, recovered MSC-treated islets infused at the intraportal site had double the average islet area compared to untreated islets (Rackham et al. 2014). Subsequent investigations suggested that one mechanism may be mitochondrial transfer from the MSCs to islets but it is unclear if this effect can be replicated in human islets (Rackham et al. 2020). Co-culture of MSCs with a mouse islet microvascular endothelium cell line (MS-1) may have beneficial effects on islet endothelial cell function through activation of the Wnt signalling pathway (Wang et al. 2017). While these findings collectively show that MSCs have protective effects, timely expansion of MSC populations in vitro and protocol standardisation may be clinically difficult (Rackham etal. 2018). This has prompted research into islet preculture with 'cell-free' exogenous MSC secretory factors cocktails. However, this achieved only modest success in restoring normal glycemic control in diabetic rodents (Rackham et al. 2018).

\section{Islets - differences between human and mouse}

Human islets are distributed for research use when isolated islets do not meet clinical transplant requirements and the donor had consented for research in this event. As previously noted, mouse-to-mouse islet transplants have a greater rate of success compared to human-to-mouse transplants. There are distinct differences between mouse and human islets which may underlie this disparity; we will discuss some of these similarities and differences below.

\section{Islet architecture}

$\beta$-cells are the predominant cell type in mouse islets, averaging about $70 \%$ of islet volume. They are arranged in a largely homotypic core, meaning the majority of $\beta$-cells neighbour other $\beta$-cells. This core is surrounded by a 'halo' of $\alpha$-cells, in addition to smaller numbers of $\delta$-, PP, and $\varepsilon$-cells (Fig. 1). Mouse islets are usually round or oval in shape, and in normal animals, there is little divergence from the norm.

During the developmental stage, $\beta$-cell arrangement in humans is similar to mice (Jeon et al. 2009). In the adult, some human islets also share a similar cellular arrangement to mouse islets, perhaps dependent on islet size (Bonner-Weir et al. 2015). However, in other islets, $\beta$-cells are arranged in streams, interspersed between $\alpha$ and $\delta$-cells (Fig. 1). Human islets also come in a wider range of sizes and shapes than normal mouse islets. In an obese but normal glucose tolerant person, human islets can be over $500 \mu \mathrm{m}$ in size, whereas in normal mice, islets are usually $150 \mu \mathrm{m}$. For small human islets, $\beta$-cells constitute the majority cell type, but large islets possess a similar proportion of $\alpha$ - and $\beta$-cells (Kim et al. 2009). In a person with normal glucose tolerance, the proportion of $\beta$-cells in human islets is lower than that in mice, being 48-59\% (Cabrera et al. 2006).

It is likely that despite having more $\beta$-cells, very large islets are dis-advantageous for transplantation. When islets are isolated, they are removed from their original blood supply, limiting the diffusion of oxygen and nutrient supplied from the outside surface. Thus, hypoxia provides a great challenge for islet survival. Larger islets by definition have a greater distance from the surface to the centre, possibly impairing survival of the islet core (Komatsu et al. 2017). Very large islets are frequently isolated from overweight or obese human donors, but these often undergo central or complete necrosis or apoptosis (Burke et al. 2016). We suggest that larger islets are likely to contribute to the relatively lower tolerance of human islets to the isolation and transplant process. Isolated islets intended for transplantation are categorised using the islet equivalent number (IEQ) scale where one IEQ represents an islet sphere of $150 \mu \mathrm{m}$ diameter. Taking these factors into account, we propose that larger islets should be assigned a lesser weighting on the IEQ scale in consideration of their predicted smaller contribution

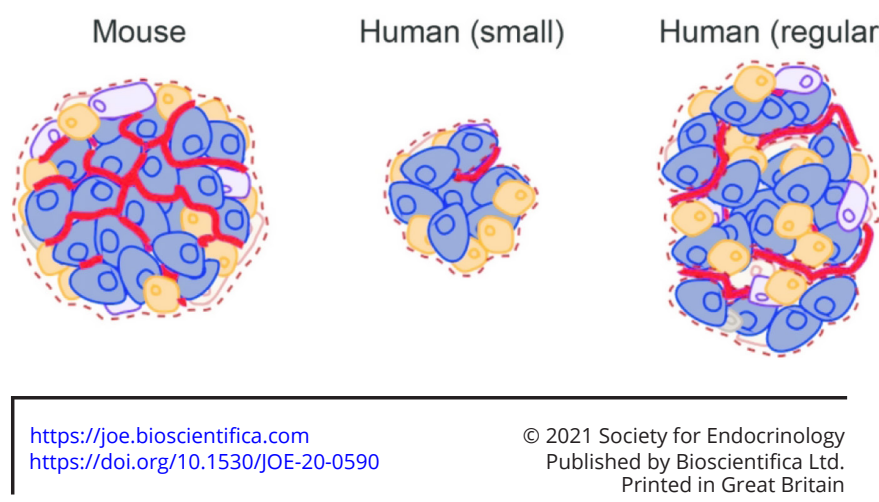

$\beta$-cells

$\alpha$-cells

ठ-cells

PP-cells

$\varepsilon$-cells

\section{Figure 1}

Schematic of endocrine cells arrangement in mouse, and small and regular-sized human islets of Langerhans. The islet vasculature network is depicted in red. Broken lines represent the basement membrane. https://joe.bioscientifica.com https://doi.org/10.1530/JOE-20-0590
Published by Bioscientifica Ltd. Printed in Great Britain 
to recipient glycemic control. The total IEQ isolated per kilogram of recipient weight is a major factor in the decision of whether islets will be transplanted.

\section{Islet vasculature and basement membrane}

Mouse pancreatic islets possess high capillary density and have a surrounding outer capsule and basement membrane that is in contact with individual $\beta$-cells. Possibly formed by endothelial cells, the basement membrane acts as an ECM and is thought to play a role in insulin production and release, and cell proliferation. In humans, blood vessels in islets are surrounded by a double layer basement membrane but there is no outer-islet capsule (Kragl \& Lammert 2010). This may make them more susceptible to fragmentation. The proteins in the murine islet extracellular matrix have been characterised, but less is known about these proteins in human islets (Llacua et al. 2018).

ECM components such as collagen or fibronectin are important for angiogenesis. Arterial blood flow is up to 20 times greater (by weight) in islets compared to the exocrine pancreas. In rats, this amounts to about $10-15 \%$ of total blood flow in the pancreas (Jansson \& Hellerström 1983). This network is disrupted during isolation whereby islets are in an avascular state post transplantation (Irving-Rodgers et al. 2014). Thus, core hypoxia, leading to cell death becomes a major issue, as inadequate oxygen and nutrients diffuses from the periphery to the core. This issue permeates the steps of the isolation, culture, and transplantation process, contributing to graft failure. Revascularisation commences approximately 3 days after engraftment and can take up to one month to complete (Gibly et al. 2011). Increased necrosis and apoptosis in avascular islets led to a substantial loss in islet mass by $72 \mathrm{~h}$ after transplant (Biarnés et al. 2002). Presently, there is no proangiogenic drug approved by the Food and Drug Administration (FDA). Preculturing without supplementation appears to inhibit vascular engraftment (Olsson \& Carlsson 2005). Transplantation of MSC-endothelial cell islet composites or the engineering of supportive synthetic scaffolds may stimulate angiogenesis (Takahashi et al. 2018, Bowers et al. 2019).

Human islets exhibit a five-fold less dense vasculature per islet area (Brissova et al. 2015), making them even more likely to succumb to these problems. Indeed, there was a $64 \%$ reduction in human islet vascular fraction 8 weeks post transplantation into the anterior chamber of the mouse eye (Cohrs et al. 2017). Interestingly, blood flow direction also differs between the two species, influenced by islet cell organisation. In humans, blood flows either in a polarised manner, from one side of the islet to the other, or travels outward from the islet core to the mantle from a primary feeding arteriole. (Christoffersson et al. 2010, Tang et al. 2018). It is possible that variations in blood flow directionality is linked to islet size, dependent upon the variability in human islet cytoarchitecture seen between small and large islets, concentrating around $\beta$-cell clusters to support their high oxygen needs (Bonner-Weir et al. 2015). Corroborating this notion is the reported polarisation of $\beta$-cells, where the majority of insulin granules are located at a distinct basal region adjacent to the islet blood vessels.

In rodents, three different blood flow patterns have been described in medium to large islets $(160-500 \mu \mathrm{m})$ : the arteriole feeds the inner islet core, and blood then flows outwards to arrive at non- $\beta$-cells, other endocrine cells are first supplied at the periphery before travelling towards the $\beta$-cell core, or from one pole of the islet to another. In general, core to peripheral cell blood flow is the most common pattern, perhaps also reflective of the spatial arrangement of mouse endocrine cells. Polar or outer-to inner directional flow was found in $40 \%$ of islets (Nyman et al. 2008). In mice, there are high levels of contact between endocrine cells and vasculature (>90\%) which could allow greater flexibility. In both species, islet size does not influence vascular fraction. Post transplantation, the revascularisation pattern may be influenced by blood flow direction and by donor age (Cohrs et al. 2017).

Islets isolated from T2D patients exhibit greater vasculature density than non-diabetic controls. A higher frequency of vessel fragmentation accounts for this observation which in turn may contribute to $\beta$-cell dysfunction and death (Brissova et al. 2015). This change is also observed in T1D islet vessels (Canzano et al. 2019). Loss of $\beta$-cell mass may also bring the vasculature closer together.

\section{Islet innervation}

Innervation in islets also differs between mice and humans. The murine islet core of $\beta$-cells is largely innervated by parasympathetic fibres, and the outer part of the islet containing $\alpha$ - and other cell types are densely supplied by both sympathetic and parasympathetic nerves (Rodriguez-Diaz et al. 2011a, Tang et al. 2014). Interestingly, young ob/ob and $\mathrm{db} / \mathrm{db}$ mice, often used as a model for T2D were found to have $49 \%$ greater sympathetic nerve density than their lean littermate counterparts. Islets undergoing chronic sympathetic stress are postulated to accelerate $\beta$-cell degeneration (Chien et al. 2016). In contrast, human islets have comparatively sparse innervation and some islets have no detectable 
innervation of endocrine cells. Instead, the sympathetic axons are in contact with pericytes and smooth muscle cells of the vasculature; this enables the stimulation of contractile cells of the islet vascular network to control of the rate of blood flow in the islet vasculature by changing blood vessel diameter (Almaça et al. 2018). Thus, input from the ANS may play an important role in human islet function by driving endocrine signalling to cells downstream of release sites in order to modulate overall insulin secretion (Rodriguez-Diaz et al. 2011b). Similarly, diabetic human islets are also more densely innervated as seen in diabetic mouse models (Tang et al. 2018).

Overall, there is a lack of studies analysing reinnervation of islets after transplantation. The rate of innervation is difficult to assess in humans post transplantation. A wide range of tracers and probes intended for in vivo $\beta$-cell imaging using magnetic resonance imaging (MRI), optical imaging, positron emission tomography (PET), and single-photon emission computed tomography (SPECT) are under evaluation in preclinical and clinical settings (Wei et al. 2019). In extracted tissue samples, the development of optical clearing techniques used with confocal and light sheet microscopy allows for mapping of graft reinnervation. Islet grafts obtained in mice at different time points revealed that there was projection of sympathetic nerves to $\alpha$-cells 3 weeks post-transplantation under the kidney capsule. After 6 weeks, sympathetic nerve density in diabetic mouse recipients only reached $60 \%$ of that of pancreatic islets measured in situ (Juang et al. 2014). Optical clearing methods have also challenged the previous notion that there is minimal projection of sympathetic and parasympathetic nerve projection into the human islet core (Tang et al. 2018).

In mouse transplants, the transplantation site affects the rate of innervation (Korsgren et al. 1993). Extrapolating this data, reinnervation efficiency may contribute to the differences in transplant success that vary by organ location. It is interesting to note that the reinnervation of islets is mostly derived from sympathetic nervous system in the liver or spleen, but a mixture in the kidney capsule which may contribute to the greater transplant success rates observed at this site (Stokes et al. 2017).

\section{Alternative strategies of sourcing $\beta$-cells}

\section{Stimulating beta-cell proliferation in vivo}

The difficulty in obtaining human islets suitable for transplantation has directed considerable research focus into sourcing an adjunct pool of islets suitable for transplantation or replenishing $\beta$-cells lost in diabetes pathogenesis. Inducing endogenous $\beta$-cell proliferation in diabetic subjects to counteract dysglycemia may circumvent the long wait for a suitable donor.

In humans, after the neonatal period, there is a sharp decrease in $\beta$-cell proliferation, with this being notably muted in adults at under $0.5 \%$ (Meier et al. 2008, Gregg et al. 2012). A decline of $\beta$-cell proliferation is also observed in mice (Krishnamurthy et al. 2006). There is also little evidence of $\beta$-cell regeneration capacity in the adult human pancreas. However, a small number of studies show that under certain circumstances, human $\beta$-cells do display ability to proliferate (Ogilvie 1933, Van Assche et al. 1978, Butler et al. 2010). In contrast, mice show excellent regeneration capacity, at least when young.

In humans, compensatory $\beta$-cell hyperplasia correlates with weight gain in the absence of diabetes (Rahier $e t$ al. 2008). Overweight and obese people who maintain normal glucose tolerance have increased $\beta$-cell mass compared to lean normal people, suggesting that they have had increased $\beta$-cell proliferation over time (Ogilvie 1933). Conversely, their weight matched counterparts with T2D have decreased $\beta$-cell mass accompanied by increased $\beta$-cell loss by apoptosis. Donors with T2D have markedly greater adipocyte infiltration in the whole pancreas compared to the overweight and obese with normal glucose tolerance (Tang et al. 2018). By contrast, diabetic mice fed a high fat diet with significant weight gain have increased $\beta$-cell mass and proliferation compared to mice that consumed a normal diet (Peyot et al. 2010).

$\beta$-cell mass increases during pregnancy, mostly mediated by prolactin and placental lactogen. This is more prominent in mice, compared to humans (Van Assche et al. 1978, Parsons et al. 1992, Butler et al. 2010). Normal pregnancy is a state of insulin resistance, particularly in the third trimester when some women develop gestational diabetes. Women who maintain normal glucose tolerance in pregnancy do so by increasing their $\beta$-cell function. Total $\beta$-cell function is determined by $\beta$-cell mass and the function of individual $\beta$-cells. There are only small autopsy studies looking at $\beta$-cell mass in pregnant women, but it appears that there is a significant increase in $\beta$-cell mass in normal pregnancy (Van Assche et al. 1978, Butler et al. 2010). Interestingly, the earlier study involving a larger number of younger women had an increase in $\beta$-cell number, whereas in the second study where there were a higher number of older pregnant women, there was a greater increase in $\beta$-cell area rather than number. This suggests the possibility of an age-related decline in capacity of $\beta$-cells to proliferate in response to 
pregnancy. It is consistent with maternal age being a major risk factor for gestational diabetes (Freinkel 1980).

The mechanism via which prolactin acts is at least partly through the inhibition of menin, a transcriptional regulator (Karnik et al. 2007). Numerous other mitogenic stimuli or pathways have been shown in mice, and ex vivo and grafted human islets to have the potential to promote $\beta$-cell proliferation. These include glucose itself (Levitt et al. 2011), glycogen synthase kinase 3 beta (GSK3B) inhibition (Shen et al. 2015), phosphorylated AKT (Hughes \& Huang 2011), and gamma-aminobutyric acid (GABA) (Soltani et al. 2011) (Fig. 2). However, the lack of uniform donor characteristics and recipients used to examine the efficacy of these mitogens may contribute to the conflicting findings reported. For example, grafted human islets exposed to chronic hyperglycemia in mice did not have a higher proliferation rate than those in normoglycemic mice (Dai et al. 2016). A possible explanation could be that islets used in Dai et al. (2016) were from healthy, non-diabetic human donors whereas the study by Levitt et al. (2011) who found that glucose infusion did indeed induce human $\beta$-cell proliferation in grafts also observed that this was positively correlated with increasing donor body mass index (BMI). As mentioned earlier, in nondiabetic humans, as BMI increases, so does $\beta$-cell mass. Another example of this is the ectopic expression of the transcription factor paired box 4 (PAX4). Mouse PAX4 stimulates $\beta$-cell proliferation in human islets, yet human PAX4 does not (Brun et al. 2004).

Mitogens that do stimulate $\beta$-cell proliferation could pose as novel treatment strategies, but a common pattern is that the increase in proliferation is often small (up to $2-4 \%$ proliferation rate from $\leq 1 \%$ ). This suggests stimulating $\beta$-cell proliferation may be a complementary, but not a frontline therapy for treating diabetes.

\section{Alpha to beta cell transdifferentiation}

Another area that has gained attention is the induction of $\alpha$-cell transdifferentiation into $\beta$-cells. During development, pancreatic ductal, endocrine and exocrine cells arise from a common multipotent progenitor. Transdifferentiation is a related but different process when already differentiated cells are converted into a different cell type (Fig. 3). While $\beta$-cells are terminally differentiated, in rodents, adult endocrine and exocrine cells possess remarkable plasticity, giving a potential avenue for sourcing $\beta$-cells. This has been shown in mouse models of profound $\beta$-cell loss and lineage tracing experiments. Some studies report bihormonal expression of insulin and glucagon in mouse $\alpha$-cells after near total $\beta$-cell destruction, while others have observed age-dependent spontaneous reprogramming of mouse $\delta$-cells into insulin producing cells (Thorel et al. 2010, Chera et al. 2014). Other groups have successfully

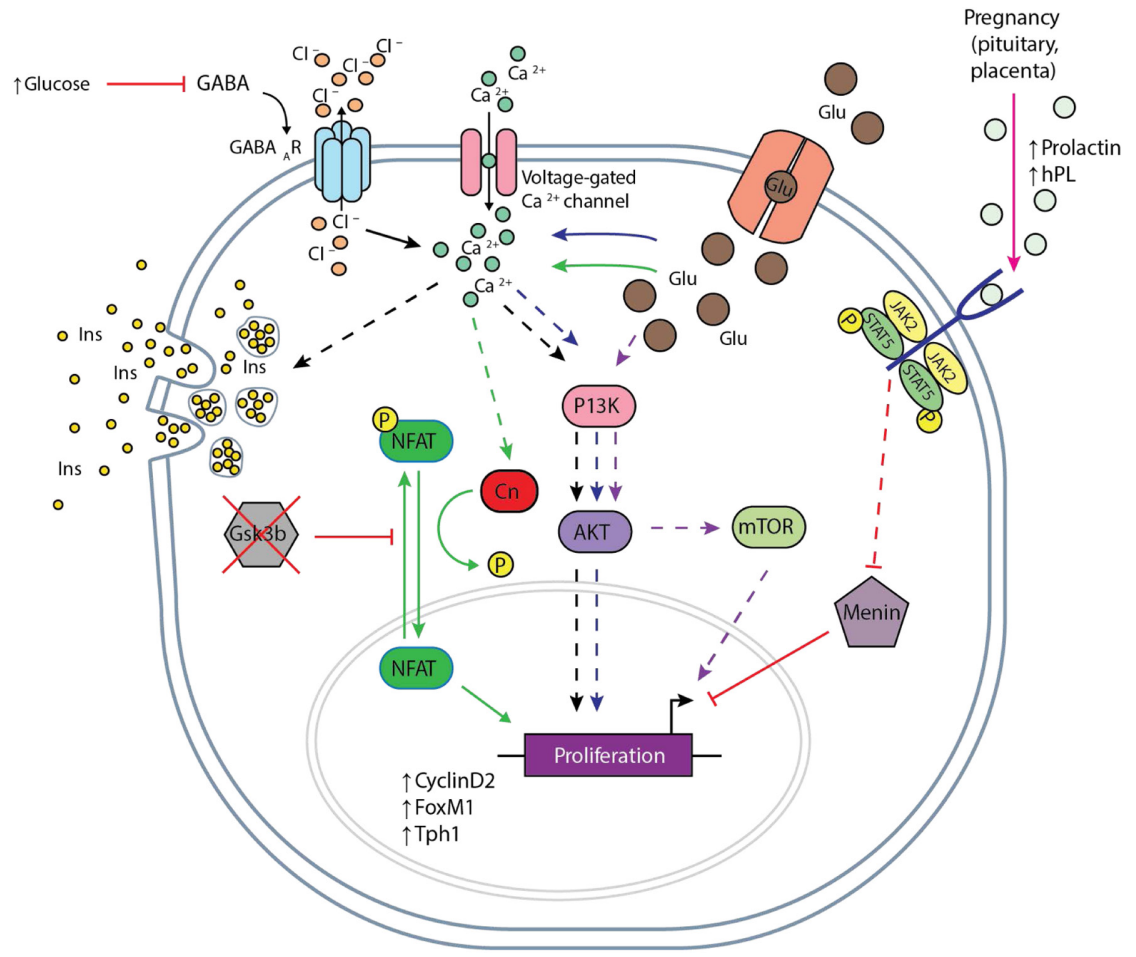

Figure 2

A number of mitogens have been implicated in promoting $\beta$-cell proliferation in mice and humans. These are summarised in this figure. Influx of glucose into the cell either activates PI3K/ AKT/mTOR signalling (purple arrow), or the resulting $\mathrm{Ca}^{2+}$ influx activates $\mathrm{PI} / 3 \mathrm{~K} / \mathrm{AKT} / \mathrm{mTOR}$ signalling (blue arrow) or calcineurin which dephosphorylates NFAT (green arrow) to stimulate $\beta$-cell proliferation. Activation of $G A B A_{A} R$ $\mathrm{Cl}$ - channel depolarises the membrane to allow the entry of $\mathrm{Ca}^{2+}$ into the cell (black arrow) which signals through the PI3K/AKT/mTOR pathway. Hormones released during pregnancy activate the JAK2/STAT5 pathway which inhibits the antiproliferative effects of menin (pink arrow). AKT, protein kinase $\mathrm{B} ; \mathrm{Cn}$, calcineurin; FoxM1, forkhead box protein $\mathrm{M} 1 ; \mathrm{GABA}_{\mathrm{A}} \mathrm{R}$, GABA type A receptor; $\mathrm{hPL}$, human placental lactogen; JAK2, Janus kinase 2; mTOR, mechanistic target of rapamycin; NFAT, nuclear factor of activated T-cells;PI3K, phosphoinositide 3-kinase; STAT5, signal transducer and activator of transcription 5, Tph1, tryptophan hydroxylase 1. 
A

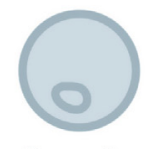

Progenitor

B

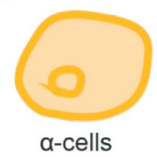

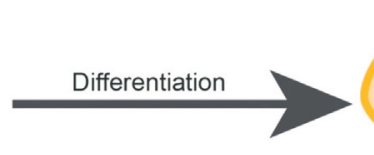

a-cells

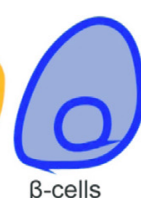

$\beta$-cells

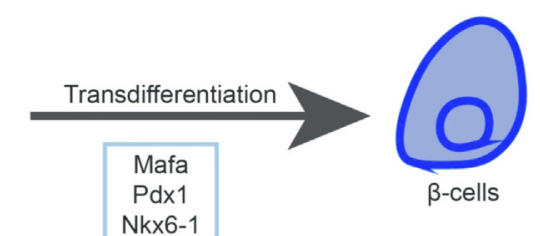

Figure 3

Endocrine cell $(A)$ differentiation and $(B)$ transdifferentiation. Transdifferentiation of $\alpha$-cells into $\beta$-cells can be induced through the ectopic expression of transcription factors important in $\beta$-cell development and maturation.

induced endocrine cell transdifferentiation in mouse $\alpha$-cells, largely through the overexpression of transcription factors required for $\beta$-cell development such as PDX1 (pancreatic and duodenal homeobox 1), or maturation such as MAFA (MAF bZIP transcription factor A, important for murine maturation) (Matsuoka et al. 2017, Xiao et al. 2018). There is also a field of research on ductal and acinar cells reprogramming into $\beta$-cells (Bonner-Weir et al. 1993, Desai et al. 2007). This is covered in more detail in the following reviews (Wei \& Hong 2016, Aguayo-Mazzucato $\&$ Bonner-Weir 2018).

During the early developmental stages, human glucagon-positive cells co-express insulin (9-21 weeks old foetus) (Jeon et al. 2009). However, the capacity for adult human endocrine cells to transdifferentiate is questioned. Examination of pancreata and islets isolated from T1D patients found no evidence of $\alpha$ - to $\beta$-cell differentiation (Brissova et al. 2018). On the other hand, bihormonal expression in endocrine cells during pregnancy or in T2D pancreas has been reported (Butler et al. 2013, Yoneda et al. 2013). Recent advances in genome sequencing techniques have allowed the mapping of endocrine cell gene expression profile. Chromatin profiling using ATAC-seq (Assay for Transposase Accessible Chromatin with high-throughput sequencing) of human $\alpha$ - and $\beta$-cells lends support to the notion of $\alpha$-cell epigenomic plasticity. Sorted human $\alpha$-cells shared a similar open chromatin profile for genes that were found to be specific to $\beta$-cells, indicative of a fluid cellular identity (Ackermann et al. 2016). Further support for transdifferentiation in human pancreatic cells was recently demonstrated by Furuyama et al. (2019) using human islets. Murine $\beta$-cell transcription factors PDX1, MAFA and NKX6-1 (NK6 homeobox 1) were transduced into purified human $\alpha$-cells using a bicistronic adenoviral vector prior to transplantation into diabetic immunodeficient mice. Achieving approximately a $38 \%$ success rate with the combination of PDX1 and MAFA, the transplanted cells were functional with diabetic mice demonstrating normoglycemia for up to 6 months. It is unclear why $\sim 62 \%$ of cells did not undergo transdifferentiation. Perhaps success was influenced by transduction efficiency, or that the successful groups of transdifferentiated $\beta$-cells shared a particular baseline phenotype (Furuyama et al. 2019). Cellular heterogeneity in $\beta$-cells is well documented (Benninger \& Hodson 2018).

In mice, a low $\alpha$-cell count is sufficient to prevent dysregulation and maintain the counter-regulatory action of glucagon in both normal and diabetic mice (Shiota et al. 2013). The situation is less clear in humans; our ability to measure $\alpha$-cell function in vivo is less exact than measuring $\beta$-cell function. Similar to $\beta$-cell mass, we cannot accurately measure $\alpha$-cell mass in a living person. Human islets have a greater number of $\alpha$-cells, and some studies suggest $\alpha$-cell mass expansion in T1D and T2D diabetic humans (Klöppel et al. 1985, Cinti et al. 2016). However, a recent study refutes this in the context of T1D (Brissova et al. 2018). Evaluation of T1D $\alpha$-cells found a decline in functional activity. The $\alpha$-cells also had altered expression of transcription factors important in preserving $\alpha$ - and $\beta$-cell identity (Brissova et al. 2018). Another study reports no change in $\alpha$-cell mass in T2D (Marselli et al. 2014). Overall, transdifferentiation may also be a limited strategy for treating diabetes.

\section{Conclusion}

Human islet transplantation is a therapeutic option to treat diabetes, although there is still varied success in clinical outcomes. There is considerable interest in alternative sources of islets such as stimulating endocrine cell proliferation and transdifferentiation. However, these strategies are still in early stages. While using murine models allows for controlled studies that target specific pathways or genes, there are often challenges in translating findings, perhaps due to the fundamental differences in islet physiology between the mouse and human.

These differences can be partly overcome by using a 'humanised model' where human islets are transplanted in the diabetic mouse (or other animal), allowing study of human islets after transplantation. Better understanding of factors influencing human islet survival will help to 
optimise human transplant outcomes. In summary, islet transplantation remains a promising treatment, with the outcomes steadily improving over time, but further refinements are still needed to achieve the very high rates of success seen with whole pancreas transplants.

\section{Declaration of interest}

The authors declare that there is no conflict of interest that could be perceived as prejudicing the impartiality of this review.

\section{Funding}

The author would like to acknowledge funding from NHMRC, DART and JDRF.

\section{References}

Ackermann AM, Wang Z, Schug J, Naji A \& Kaestner KH 2016 Integration of ATAC-seq and RNA-seq identifies human alpha cell and beta cell signature genes. Molecular Metabolism 5 233-244. (https://doi. org/10.1016/j.molmet.2016.01.002)

Aguayo-Mazzucato C \& Bonner-Weir S 2018 Pancreatic $\beta$ cell regeneration as a possible therapy for diabetes. Cell Metabolism 27 57-67. (https:// doi.org/10.1016/j.cmet.2017.08.007)

Almaça J, Weitz J, Rodriguez-Diaz R, Pereira E \& Caicedo A 2018 The pericyte of the pancreatic islet regulates capillary diameter and local blood flow. Cell Metabolism 27 630-644.e4. (https://doi.org/10.1016/j. cmet.2018.02.016)

Atkinson MA \& Eisenbarth GS 2001 Type 1 diabetes: new perspectives on disease pathogenesis and treatment. Lancet 358 221-229 (https://doi. org/10.1016/S0140-6736(01)05415-0)

Barra JM \& Tse HM 2018 Redox-dependent inflammation in islet transplantation rejection. Frontiers in Endocrinology 9175 (https://doi. org/10.3389/fendo.2018.00175)

Benedini S, Ermetici F, Briganti S, Codella R, Terruzzi I, Maffi P, Caldara R, Secchi A, Nano R, Piemonti L, et al. 2018 Insulin-mimetic effects of short-term rapamycin in type 1 diabetic patients prior to islet transplantation. Acta Diabetologica 55 715-722 (https://doi. org/10.1007/s00592-018-1141-z)

Bennet W, Groth CG, Larsson R, Nilsson B \& Korsgren O 2000 Isolated human islets trigger an instant blood mediated inflammatory reaction: implications for intraportal islet transplantation as a treatment for patients with type 1 diabetes. Upsala Journal of Medical Sciences 105 125-133 (https://doi.org/10.1517/03009734000000059)

Benninger RKP \& Hodson DJ 2018 New understanding of $\beta$-cell heterogeneity and in situ islet function. Diabetes 67 537-547 (https:// doi.org/10.2337/dbi17-0040)

Biarnés M, Montolio M, Nacher V, Raurell M, Soler J \& Montanya E 2002 $\beta$-cell death and mass in syngeneically transplanted islets exposed to short- and long-term hyperglycemia. Diabetes 51 66-72 (https://doi. org/10.2337/diabetes.51.1.66)

Bonner-Weir S, Baxter LA, Schuppin GT \& Smith FE 1993 A second pathway for regeneration of adult exocrine and endocrine pancreas: a possible recapitulation of embryonic development. Diabetes $\mathbf{4 2}$ 1715-1720 (https://doi.org/10.2337/diab.42.12.1715)

Bonner-Weir S, Sullivan BA \& Weir GC 2015 Human islet morphology revisited: human and rodent islets are not so different after all. Journal of Histochemistry and Cytochemistry 63 604-612 (https://doi. org/10.1369/0022155415570969)
Bowers DT, Song W, Wang LH \& Ma M 2019 Engineering the vasculature for islet transplantation. Acta Biomaterialia 95 131-151 (https://doi. org/10.1016/j.actbio.2019.05.051)

Brennan DC, Kopetskie HA, Sayre PH, Alejandro R, Cagliero E, Shapiro AMJ, Goldstein JS, Desmarais MR, Booher S \& Bianchine PJ 2016 Long-term follow-up of the Edmonton protocol of islet transplantation in the United States. American Journal of Transplantation 16 509-517 (https://doi.org/10.1111/ajt.13458)

Brissova M, Haliyur R, Saunders D, Shrestha S, Dai C, Blodgett DM, Bottino R, Campbell-Thompson M, Aramandla R, Poffenberger G, et al. $2018 \propto$ Cell function and gene expression are compromised in type 1 diabetes. Cell Reports 22 2667-2676 (https://doi.org/10.1016/j. celrep.2018.02.032)

Brissova M, Shostak A, Fligner CL, Revetta FL, Washington MK, Powers AC \& Hull RL 2015 Human islets have fewer blood vessels than mouse islets and the density of islet vascular structures is increased in type 2 diabetes. Journal of Histochemistry and Cytochemistry 63 637-645 (https://doi. org/10.1369/0022155415573324)

Brun T, Franklin I, St-Onge L, Biason-Lauber A, Schoenle EJ, Wollheim CB \& Gauthier BR 2004 The diabetes-linked transcription factor PAX4 promotes $\beta$-cell proliferation and survival in rat and human islets. Journal of Cell Biology 167 1123-1135 (https://doi.org/10.1083/ jcb.200405148)

Burke SJ, Karlstad MD \& Collier JJ 2016 Pancreatic islet responses to metabolic trauma. Shock 46 230-238 (https://doi.org/10.1097/ SHK.0000000000000607)

Butler AE, Campbell-Thompson M, Gurlo T, Dawson DW, Atkinson M \& Butler PC 2013 Marked expansion of exocrine and endocrine pancreas with incretin therapy in humans with increased exocrine pancreas dysplasia and the potential for glucagon-producing neuroendocrine tumors. Diabetes 62 2595-2604 (https://doi.org/10.2337/db12-1686)

Butler AE, Cao-Minh L, Galasso R, Rizza RA, Corradin A, Cobelli C \& Butler PC 2010 Adaptive changes in pancreatic beta cell fractional area and beta cell turnover in human pregnancy. Diabetologia $\mathbf{5 3}$ 2167-2176 (https://doi.org/10.1007/s00125-010-1809-6)

Butler AE, Dhawan S, Hoang J, Cory M, Zeng K, Fritsch H, Meier JJ, Rizza RA \& Butler PC $2016 \beta$-cell deficit in obese type 2 diabetes, a minor role of $\beta$-cell dedifferentiation and degranulation. Journal of Clinical Endocrinology \& Metabolism 101 523-532 (https://doi. org/10.1210/jc.2015-3566)

Butler AE, Janson J, Bonner-Weir S, Ritzel R, Rizza RA \& Butler PC $2003 \beta$-cell deficit and increased $\beta$-cell apoptosis in humans with type 2 diabetes. Diabetes 52 102-110 (https://doi.org/10.2337/ diabetes.52.1.102)

Cabrera O, Berman DM, Kenyon NS, Ricordi C, Berggren PO \& Caicedo A 2006 The unique cytoarchitecture of human pancreatic islets has implications for islet cell function. Proceedings of the National Academy of Sciences of the United States of America 103 2334-2339 (https://doi. org/10.1073/pnas.0510790103)

Canzano JS, Nasif LH, Butterworth EA, Fu DA, Atkinson MA \& CampbellThompson M 2019 Islet microvasculature alterations with loss of beta-cells in patients with type 1 diabetes. Journal of Histochemistry and Cytochemistry 67 41-52 (https://doi.org/10.1369/0022155418778546)

Carlsson PO, Palm F, Andersson A \& Liss P 2001 Markedly decreased oxygen tension in transplanted rat pancreatic islets irrespective of the implantation site. Diabetes 50 489-495 (https://doi.org/10.2337/ diabetes.50.3.489)

Chera S, Baronnier D, Ghila L, Cigliola V, Jensen JN, Gu G, Furuyama K, Thorel F, Gribble FM, Reimann F, et al. 2014 Diabetes recovery by age-dependent conversion of pancreatic $\delta$-cells into insulin producers. Nature 514 503-507 (https://doi.org/10.1038/nature13633)

Chien HJ, Peng SJ, Hua TE, Kuo CH, Juang JH \& Tang SC 2016 3-D imaging of islets in obesity: formation of the islet-duct complex and neurovascular remodeling in young hyperphagic mice. International Journal of Obesity 40 685-697 (https://doi.org/10.1038/ijo.2015.224) https://joe.bioscientifica.com

https://doi.org/10.1530/JOE-20-0590 (c) 2021 Society for Endocrinology Published by Bioscientifica Ltd. Printed in Great Britain 
Christoffersson G, Henriksnäs J, Johansson L, Rolny C, Ahlström H, Caballero-Corbalan J, Segersvärd R, Permert J, Korsgren O, Carlsson PO, et al. 2010 Clinical and experimental pancreatic islet transplantation to striated muscle: establishment of a vascular system similar to that in native islets. Diabetes 59 2569-2578 (https://doi. org/10.2337/db10-0205)

Cinti F, Bouchi R, Kim-Muller JY, Ohmura Y, Sandoval PR, Masini M, Marselli L, Suleiman M, Ratner LE, Marchetti P, et al. 2016 Evidence of $\beta$-cell dedifferentiation in human type 2 diabetes. Journal of Clinical Endocrinology \& Metabolism 101 1044-1054 (https://doi.org/10.1210/ jc.2015-2860)

Cohrs CM, Chen C, Jahn SR, Stertmann J, Chmelova H, Weitz J, Bähr A, Klymiuk N, Steffen A, Ludwig B, et al. 2017 Vessel network architecture of adult human islets promotes distinct cell-cell interactions in situ and is altered after transplantation. Endocrinology 158 1373-1385 (https://doi.org/10.1210/en.2016-1184)

Cross SE, Vaughan RH, Willcox AJ, Mcbride AJ, Abraham AA, Han B, Johnson JD, Maillard E, Bateman PA, Ramracheya RD, et al. 2017 Key matrix proteins within the pancreatic islet basement membrane are differentially digested during human islet isolation. American Journal of Transplantation 17 451-461 (https://doi.org/10.1111/ajt.13975)

Dahan T, Ziv O, Horwitz E, Zemmour H, Lavi J, Swisa A, Leibowitz G, Ashcroft FM, In't Veld P, Glaser B, et al. 2017 Pancreatic $\beta$-cells express the fetal islet hormone gastrin in rodent and human diabetes. Diabetes 66 426-436 (https://doi.org/10.2337/db16-0641)

Dai C, Kayton NS, Shostak A, Poffenberger G, Cyphert HA, Aramandla R, Thompson C, Papagiannis IG, Emfinger C, Shiota M, et al. 2016 Stress-impaired transcription factor expression and insulin secretion in transplanted human islets. Journal of Clinical Investigation $\mathbf{1 2 6}$ 1857-1870 (https://doi.org/10.1172/JCI83657)

Das A, Huang GX, Bonkowski MS, Longchamp A, Li C, Schultz MB, Kim L-J, Osborne B, Joshi S, Lu Y, et al. 2018 Impairment of an endothelial NAD +-H2S signaling network is a reversible cause of vascular aging. Cell 173 74-89.e20 (https://doi.org/10.1016/j. cell.2018.02.008)

Davalli AM, Ogawa Y, Ricordi C, Scharp DW, Bonner-Weir S \& Weir GC 1995 A selective decrease in the beta cell mass of human islets transplanted into diabetic nude mice. Transplantation 59 817-820 (https://doi.org/10.1097/00007890-199503000-00003)

De Vos A, Heimberg H, Quartier E, Huypens P, Bouwens L, Pipeleers D \& Schuit F 1995 Human and rat beta cells differ in glucose transporter but not in glucokinase gene expression. Journal of Clinical Investigation 96 2489-2495 (https://doi.org/10.1172/JCI118308)

Desai BM, Oliver-Krasinski J, De Leon DD, Farzad C, Hong N, Leach SD \& Stoffers DA 2007 Preexisting pancreatic acinar cells contribute to acinar cell, but not islet beta cell, regeneration. Journal of Clinical Investigation 117 971-977 (https://doi.org/10.1172/JCI29988)

Eizirik DL, Pipeleers DG, Ling Z, Welsh N, Hellerström C \& Andersson A 1994 Major species differences between humans and rodents in the susceptibility to pancreatic beta-cell injury. Proceedings of the National Academy of Sciences of the United States of America 91 9253-9256 (https://doi.org/10.1073/pnas.91.20.9253)

Freinkel N 1980 Banting Lecture 1980: of pregnancy and progeny. Diabetes 29 1023-1035 (https://doi.org/10.2337/diab.29.12.1023)

Froud T, Ricordi C, Baidal DA, Hafiz MM, Ponte G, Cure P, Pileggi A, Poggioli R, Ichii $\mathrm{H}$, Khan A, et al. 2005 Islet transplantation in type 1 diabetes mellitus using cultured islets and steroid-free immunosuppression: Miami experience. American Journal of Transplantation 5 2037-2046 (https://doi.org/10.1111/j.16006143.2005.00957.x)

Furuyama K, Chera S, Van Gurp L, Oropeza D, Ghila L, Damond N, Vethe H, Paulo JA, Joosten AM, Berney T, et al. 2019 Diabetes relief in mice by glucose-sensing insulin-secreting human $\alpha$-cells. Nature 567 43-48 (https://doi.org/10.1038/s41586-019-0942-8)

Gan WJ, Do OH, Cottle L, Ma W, Kosobrodova E, Cooper-White J, Bilek M \& Thorn P 2018 Local integrin activation in pancreatic $\beta$ cells targets insulin secretion to the vasculature. Cell Reports 24 2819-2826. e3 (https://doi.org/10.1016/j.celrep.2018.08.035)

Gibly RF, Graham JG, Luo X, Lowe Jr WL, Hering BJ \& Shea LD 2011 Advancing islet transplantation: from engraftment to the immune response. Diabetologia 54 2494-2505 (https://doi.org/10.1007/s00125011-2243-0)

Gregg BE, Moore PC, Demozay D, Hall BA, Li M, Husain A, Wright AJ, Atkinson MA \& Rhodes CJ 2012 Formation of a human $\beta$-cell population within pancreatic islets is set early in life. Journal of Clinical Endocrinology and Metabolism 97 3197-3206 (https://doi. org/10.1210/jc.2012-1206)

Griffith TS, Brunner T, Fletcher SM, Green DR \& Ferguson TA 1995 Fas ligand-induced apoptosis as a mechanism of immune privilege. Science 270 1189-1192 (https://doi.org/10.1126/ science.270.5239.1189)

Gunton JE, Kulkarni RN, Yim S, Okada T, Hawthorne WJ, Tseng YH, Roberson RS, Ricordi C, O'connell PJ, Gonzalez FJ, et al. 2005 Loss of ARNT/HIF1beta mediates altered gene expression and pancreatic-islet dysfunction in human type 2 diabetes. Cell 122 337-349 (https://doi. org/10.1016/j.cell.2005.05.027)

Halvorsen TL, Beattie GM, Lopez AD, Hayek A \& Levine F 2000 Accelerated telomere shortening and senescence in human pancreatic islet cells stimulated to divide in vitro. Journal of Endocrinology 166 103-109 (https://doi.org/10.1677/joe.0.1660103)

Hering BJ, Kandaswamy R, Harmon JV, Ansite JD, Clemmings SM, Sakai T, Paraskevas S, Eckman PM, Sageshima J, Nakano M, et al. 2004 Transplantation of cultured islets from two-layer preserved pancreases in type 1 diabetes with anti-CD3 antibody. American Journal of Transplantation 4 390-401 (https://doi.org/10.1046/j.16006143.2003.00351.x)

Hughes E \& Huang C 2011 Participation of Akt, menin, and p21 in pregnancy-induced $\beta$-cell proliferation. Endocrinology 152 847-855 (https://doi.org/10.1210/en.2010-1250)

Ihm SH, Matsumoto I, Sawada T, Nakano M, Zhang HJ, Ansite JD, Sutherland DER \& Hering BJ 2006 Effect of donor age on function of isolated human islets. Diabetes 55 1361-1368 (https://doi. org/10.2337/db05-1333)

Imagawa A, Hanafusa T, Tamura S, Moriwaki M, Itoh N, Yamamoto K, Iwahashi H, Yamagata K, Waguri M, Nanmo T, et al. 2001 Pancreatic biopsy as a procedure for detecting in situ autoimmune phenomena in type 1 diabetes: close correlation between serological markers and histological evidence of cellular autoimmunity. Diabetes $\mathbf{5 0}$ 1269-1273 (https://doi.org/10.2337/diabetes.50.6.1269)

Irving-Rodgers HF, Choong FJ, Hummitzsch K, Parish CR, Rodgers RJ \& Simeonovic CJ 2014 Pancreatic islet basement membrane loss and remodeling after mouse islet isolation and transplantation: impact for allograft rejection. Cell Transplantation 23 59-72 (https://doi.org/10.3 727/096368912X659880)

Jansson L \& Carlsson PO 2002 Graft vascular function after transplantation of pancreatic islets. Diabetologia 45 749-763 (https:// doi.org/10.1007/s00125-002-0827-4)

Jansson L \& Hellerström C 1983 Stimulation by glucose of the blood flow to the pancreatic islets of the rat. Diabetologia 25 45-50 (https://doi. org/10.1007/BF00251896)

Jeon J, Correa-Medina M, Ricordi C, Edlund H \& Diez JA 2009 Endocrine cell clustering during human pancreas development. Journal of Histochemistry and Cytochemistry 57 811-824 (https://doi.org/10.1369/ jhc.2009.953307)

Johansson H, Lukinius A, Moberg L, Lundgren T, Berne C, Foss A, Felldin M, Källen R, Salmela K, Tibell A, et al. 2005 Tissue factor produced by the endocrine cells of the islets of Langerhans is associated with a negative outcome of clinical islet transplantation. Diabetes 54 1755-1762 (https://doi.org/10.2337/diabetes.54.6.1755)

Juang JH, Peng SJ, Kuo CH \& Tang SC 2014 Three-dimensional islet graft histology: panoramic imaging of neural plasticity in sympathetic reinnervation of transplanted islets under the kidney capsule. https://joe.bioscientifica.com https://doi.org/10.1530/JOE-20-0590 (c) 2021 Society for Endocrinology Published by Bioscientifica Ltd. Printed in Great Britain 
American Journal of Physiology. Endocrinology and Metabolism 306 E559-E570 (https://doi.org/10.1152/ajpendo.00515.2013)

Jung DY, Park JB, Joo SY, Joh JW, Kwon CH, Kwon GY \& Kim SJ 2009 Effect of nicotinamide on early graft failure following intraportal islet transplantation. Experimental \& Molecular Medicine 41 782-792 (https://doi.org/10.3858/emm.2009.41.11.084)

Karnik SK, Chen H, Mclean GW, Heit JJ, Gu X, Zhang AY, Fontaine M, Yen MH \& Kim SK 2007 Menin controls growth of pancreatic ß-cells in pregnant mice and promotes gestational diabetes mellitus. Science 318 806-809 (https://doi.org/10.1126/science.1146812)

Kim A, Miller K, Jo J, Kilimnik G, Wojcik P \& Hara M 2009 Islet architecture: a comparative study. Islets 1 129-136 (https://doi. org/10.4161/isl.1.2.9480)

Klöppel G, Löhr M, Habich K, Oberholzer M \& Heitz PU 1985 Islet pathology and the pathogenesis of type 1 and type 2 diabetes mellitus revisited. Survey and Synthesis of Pathology Research 4 110-125 (https:// doi.org/10.1159/000156969)

Kodama S, Toyonaga T, Kondo T, Matsumoto K, Tsuruzoe K, Kawashima J, Goto H, Kume K, Kume S, Sakakida M, et al. 2005 Enhanced expression of PDX-1 and Ngn3 by exendin- 4 during $\beta$ cell regeneration in STZtreated mice. Biochemical and Biophysical Research Communications 327 1170-1178 (https://doi.org/10.1016/j.bbrc.2004.12.120)

Kolb H, Burkart V, Appels B, Hanenberg H, Kantwerk-Funke G, Kiesel U, Funda J, Schraermeyer U \& Kolb-Bachofen V 1990 Essential contribution of macrophages to islet cell destruction in vivo and in vitro. Journal of Autoimmunity 3(Supplement 1) 117-120 (https://doi. org/10.1016/s0896-8411(09)90020-8)

Komatsu H, Cook C, Wang CH, Medrano L, Lin H, Kandeel F, Tai YC \& Mullen Y 2017 Oxygen environment and islet size are the primary limiting factors of isolated pancreatic islet survival. PLOS ONE 12 e0183780 (https://doi.org/10.1371/journal.pone.0183780)

Korsgren O, Jansson L, Andersson A \& Sundler F 1993 Reinnervation of transplanted pancreatic islets. A comparison among islets implanted into the kidney, spleen, and liver. Transplantation 56 138-143 (https:// doi.org/10.1097/00007890-199307000-00026)

Kragl M \& Lammert E 2010 Basement membrane in pancreatic islet function. In The Islets Of Langerhans. Advances in Experimental Medicine and Biology. MS Islam Ed.: Dordrecht: Springer. (https://doi. org/10.1007/978-90-481-3271-3_10)

Krishnamurthy J, Ramsey MR, Ligon KL, Torrice C, Koh A, Bonner-Weir S \& Sharpless NE 2006 p16INK4a induces an age-dependent decline in islet regenerative potential. Nature $\mathbf{4 4 3} 453-457$ (https://doi. org/10.1038/nature05092)

Krogvold L, Edwin B, Buanes T, Ludvigsson J, Korsgren O, Hyöty H, Frisk G, Hanssen KF \& Dahl-Jørgensen K 2014 Pancreatic biopsy by minimal tail resection in live adult patients at the onset of type 1 diabetes: experiences from the DiViD study. Diabetologia 57 841-843 (https://doi.org/10.1007/s00125-013-3155-y)

Kuljanin M, Elgamal RM, Bell GI, Xenocostas A, Lajoie GA \& Hess DA 2019 Human multipotent stromal cell secreted effectors accelerate islet regeneration. Stem Cells 37 516-528 (https://doi.org/10.1002/ stem.2976)

Levitt HE, Cyphert TJ, Pascoe JL, Hollern DA, Abraham N, Lundell RJ, Rosa T, Romano LC, Zou B, O'donnell CP, et al. 2011 Glucose stimulates human beta cell replication in vivo in islets transplanted into NOD-severe combined immunodeficiency (SCID) mice. Diabetologia 54 572-582 (https://doi.org/10.1007/s00125-010-1919-1)

Li Y, Xue W, Liu H, Fan P, Wang X, Ding X, Tian X, Feng X, Pan X, Zheng J, et al. 2013 Combined strategy of endothelial cells coating, Sertoli cells coculture and infusion improves vascularization and rejection protection of islet graft. PLOS ONE $\mathbf{8}$ e56696 (https://doi. org/10.1371/journal.pone.0056696)

Llacua LA, Faas MM \& De Vos P 2018 Extracellular matrix molecules and their potential contribution to the function of transplanted pancreatic islets. Diabetologia 61 1261-1272 (https://doi.org/10.1007/ s00125-017-4524-8)
Luca G, Fallarino F, Calvitti M, Mancuso F, Nastruzzi C, Arato I, Falabella G, Grohmann U, Becchetti E, Puccetti P, et al. 2010 Xenograft of microencapsulated Sertoli cells reverses T1DM in NOD mice by inducing neogenesis of beta-cells. Transplantation 90 1352-1357 (https://doi.org/10.1097/tp.0b013e3181ffb9d2)

Maffi P, Berney T, Nano R, Niclauss N, Bosco D, Melzi R, Mercalli A, Magistretti P, De Cobelli F, Battaglia M, et al. 2014 Calcineurin inhibitor-free immunosuppressive regimen in type 1 diabetes patients receiving islet transplantation: single-group Phase $1 / 2$ trial. Transplantation 98 1301-1309 (https://doi.org/10.1097/ TP.0000000000000396)

Marselli L, Suleiman M, Masini M, Campani D, Bugliani M, Syed F, Martino L, Focosi D, Scatena F, Olimpico F, et al. 2014 Are we overestimating the loss of beta cells in type 2 diabetes? Diabetologia 57 362-365 (https://doi.org/10.1007/s00125-013-3098-3)

Matsumoto I, Sawada T, Nakano M, Sakai T, Liu B, Ansite JD, Zhang HJ, Kandaswamy R, Sutherland DER \& Hering BJ 2004 Improvement in islet yield from obese donors for human islet transplants. Transplantation 78 880-885 (https://doi.org/10.1097/01. tp.0000134396.03440.1e)

Matsuoka TA, Kawashima S, Miyatsuka T, Sasaki S, Shimo N, Katakami N, Kawamori D, Takebe S, Herrera PL, Kaneto H, et al. 2017 Mafa enables Pdx1 to effectively convert pancreatic islet progenitors and committed islet $\alpha$-cells into $\beta$-cells in vivo. Diabetes 66 1293-1300 (https://doi.org/10.2337/db16-0887)

Meier JJ, Butler AE, Saisho Y, Monchamp T, Galasso R, Bhushan A, Rizza RA \& Butler PC $2008 \beta$-cell replication is the primary mechanism subserving the postnatal expansion of $\beta$-cell mass in humans. Diabetes 57 1584-1594 (https://doi.org/10.2337/db07-1369)

Moberg L, Olsson A, Berne C, Felldin M, Foss A, Källen R, Salmela K, Tibell A, Tufveson G, Nilsson B, et al. 2003 Nicotinamide inhibits tissue factor expression in isolated human pancreatic islets: implications for clinical islet transplantation. Transplantation $\mathbf{7 6}$ 1285-1288 (https://doi.org/10.1097/01.TP.0000098905.86445.0F)

Mojibian M, Harder B, Hurlburt A, Bruin JE, Asadi A \& Kieffer TJ 2013 Implanted islets in the anterior chamber of the eye are prone to autoimmune attack in a mouse model of diabetes. Diabetologia 56 2213-2221 (https://doi.org/10.1007/s00125-013-3004-z)

Negi S, Jetha A, Aikin R, Hasilo C, Sladek R \& Paraskevas S 2012 Analysis of beta-cell gene expression reveals inflammatory signaling and evidence of dedifferentiation following human islet isolation and culture. PLOS ONE 7 e30415 (https://doi.org/10.1371/journal. pone.0030415)

Niclauss N, Bosco D, Morel P, Demuylder-Mischler S, Brault C, MilliatGuittard L, Colin C, Parnaud G, Muller YD, Giovannoni L, et al. 2011 Influence of donor age on islet isolation and transplantation outcome. Transplantation 91 360-366 (https://doi.org/10.1097/ tp.0b013e31820385e6)

Noguchi H, Naziruddin B, Jackson A, Shimoda M, Ikemoto T, Fujita Y, Chujo D, Takita M, Peng H, Sugimoto K, et al. 2012 Fresh islets are more effective for islet transplantation than cultured islets. Cell Transplantation 21 517-523 (https://doi.org/10.3727/0963689 11X605439)

Nyman LR, Wells KS, Head WS, Mccaughey M, Ford E, Brissova M, Piston DW \& Powers AC 2008 Real-time, multidimensional in vivo imaging used to investigate blood flow in mouse pancreatic islets. Journal of Clinical Investigation 118 3790-3797 (https://doi. org/10.1172/JCI36209)

O'connell PJ, Holmes-Walker DJ, Goodman D, Hawthorne WJ, Loudovaris T, Gunton JE, Thomas HE, Grey ST, Drogemuller CJ, Ward GM, et al. 2013 Multicenter Australian trial of islet transplantation: improving accessibility and outcomes. American Journal of Transplantation 13 1850-1858 (https://doi.org/10.1111/ajt.12250)

Ogilvie RF 1933 The Islands of Langerhans in 19 cases of obesity. Journal of Pathology and Bacteriology 37 473-481 (https://doi.org/10.1002/ path.1700370314) 
Olsson R \& Carlsson PO 2005 Better vascular engraftment and function in pancreatic islets transplanted without prior culture. Diabetologia $\mathbf{4 8}$ 469-476 (https://doi.org/10.1007/s00125-004-1650-x)

Omori K, Kobayashi E, Rawson J, Takahashi M \& Mullen Y 2016 Mechanisms of islet damage mediated by pancreas cold ischemia/ rewarming. Cryobiology 73 126-134 (https://doi.org/10.1016/j. cryobiol.2016.08.010)

Parsons JA, Brelje TC \& Sorenson RL 1992 Adaptation of islets of Langerhans to pregnancy: increased islet cell proliferation and insulin secretion correlates with the onset of placental lactogen secretion. Endocrinology 130 1459-1466 (https://doi.org/10.1210/ endo.130.3.1537300)

Peyot ML, Pepin E, Lamontagne J, Latour MG, Zarrouki B, Lussier R, Pineda M, Jetton TL, Madiraju SRM, Joly E, et al. 2010 Beta-cell failure in diet-induced obese mice stratified according to body weight gain: secretory dysfunction and altered islet lipid metabolism without steatosis or reduced beta-cell mass. Diabetes 59 2178-2187 (https:// doi.org/10.2337/db09-1452)

Rackham CL, Amisten S, Persaud SJ, King AJF \& Jones PM 2018 Mesenchymal stromal cell secretory factors induce sustained improvements in islet function pre- and post-transplantation. Cytotherapy 20 1427-1436 (https://doi.org/10.1016/j. jcyt.2018.07.007)

Rackham CL, Dhadda PK, Le Lay AM, King AJF \& Jones PM 2014 Preculturing islets With adipose-derived mesenchymal stromal cells is an effective strategy for improving transplantation efficiency at the clinically preferred intraportal site. Cell Medicine 7 37-47 (https://doi. org/10.3727/215517914X680047)

Rackham CL, Hubber EL, Czajka A, Malik AN, King AJF \& Jones PM 2020 Optimizing beta cell function through mesenchymal stromal cellmediated mitochondria transfer. Stem Cells 38 574-584 (https://doi. org/10.1002/stem.3134)

Rahier J, Guiot Y, Goebbels RM, Sempoux C \& Henquin JC 2008 Pancreatic $\beta$-cell mass in European subjects with type 2 diabetes. Diabetes, Obesity and Metabolism 10(Supplement 4) 32-42 (https://doi. org/10.1111/j.1463-1326.2008.00969.x)

Ravassard P, Hazhouz Y, Pechberty S, Bricout-Neveu E, Armanet M, Czernichow P \& Scharfmann R 2011 A genetically engineered human pancreatic $\beta$ cell line exhibiting glucose-inducible insulin secretion. Journal of Clinical Investigation 121 3589-3597 (https://doi. org/10.1172/JCI58447)

Ricordi C, Goldstein JS, Balamurugan AN, Szot GL, Kin T, Liu C, Czarniecki CW, Barbaro B, Bridges ND, Cano J, et al. 2016 National Institutes of Health-sponsored Clinical Islet Transplantation Consortium Phase 3 trial: manufacture of a complex cellular product at eight processing facilities. Diabetes 65 3418-3428 (https://doi. org/10.2337/db16-0234)

Rodriguez-Diaz R, Abdulreda MH, Formoso AL, Gans I, Ricordi C, Berggren PO \& Caicedo A 2011a Innervation patterns of autonomic axons in the human endocrine pancreas. Cell Metabolism 14 45-54 (https://doi.org/10.1016/j.cmet.2011.05.008)

Rodriguez-Diaz R Dando R, Jacques-Silva MC, Fachado A, Molina J, Abdulreda MH, Ricordi C, Roper SD, Berggren P-O \& Caicedo A 2011b. Alpha cells secrete acetylcholine as a non-neuronal paracrine signal priming beta cell function in humans. Nature Medicine $\mathbf{1 7}$ 888-892. (https://doi.org/10.1038/nm.2371)

Selawry HP \& Cameron DF 1993 Sertoli cell-enriched fractions in successful islet cell transplantation. Cell Transplantation 2 123-129 (https://doi.org/10.1177/096368979300200206)

Shapiro AMJ, Lakey JRT, Ryan EA, Korbutt GS, Toth E, Warnock GL, Kneteman NM \& Rajotte RV 2000 Islet transplantation in seven patients with type 1 diabetes mellitus using a glucocorticoid-free immunosuppressive regimen. New England Journal of Medicine 343 230-238 (https://doi.org/10.1056/NEJM200007273430401)
Shapiro AMJ, Pokrywczynska M \& Ricordi C 2017 Clinical pancreatic islet transplantation. Nature Reviews. Endocrinology 13 268-277 (https:// doi.org/10.1038/nrendo.2016.178)

Shen W, Taylor B, Jin Q, Nguyen-Tran V, Meeusen S, Zhang YQ, Kamireddy A, Swafford A, Powers AF, Walker J, et al. 2015 Inhibition of DYRK1A and GSK3B Induces Human $\beta$-cell Proliferation. Nature Communications 68372 (https://doi.org/10.1038/ncomms9372)

Sherry NA, Tsai EB \& Herold KC 2005 Natural history of $\beta$-cell function in type 1 diabetes. Diabetes 54(Supplement 2) S32-S39 (https://doi. org/10.2337/diabetes.54.suppl_2.s32)

Shiota C, Prasadan K, Guo P, El-Gohary Y, Wiersch J, Xiao X, Esni F \& Gittes GK $2013 \alpha$-cells are dispensable in postnatal morphogenesis and maturation of mouse pancreatic islets. American Journal of Physiology. Endocrinology and Metabolism 305 E1030-E1040 (https:// doi.org/10.1152/ajpendo.00022.2013)

Soltani N, Qiu H, Aleksic M, Glinka Y, Zhao F, Liu R, Li Y, Zhang N, Chakrabarti R, Ng T, et al. 2011 GABA exerts protective and regenerative effects on islet beta cells and reverses diabetes. Proceedings of the National Academy of Sciences of the United States of America 108 11692-11697 (https://doi.org/10.1073/ pnas.1102715108)

Spijker HS, Ravelli RBG, Mommaas-Kienhuis AM, Van Apeldoorn AA, Engelse MA, Zaldumbide A, Bonner-Weir S, Rabelink TJ, Hoeben RC, Clevers $\mathrm{H}$, et al. 2013 Conversion of mature human $\beta$-cells into glucagon-producing $\alpha$-cells. Diabetes 62 2471-2480 (https://doi. org/10.2337/db12-1001)

Stice MJ, Dunn TB, Bellin MD, Skube ME \& Beilman GJ 2018 Omental pouch technique for combined site islet autotransplantation following total pancreatectomy. Cell Transplantation 27 1561-1568 (https://doi.org/10.1177/0963689718798627)

Stokes RA, Cheng K, Deters N, Lau SM, Hawthorne WJ, O'connell PJ, Stolp J, Grey S, Loudovaris T, Kay TW, et al. 2013 Hypoxia-inducible factor- $1 \alpha($ HIF- $1 \alpha)$ potentiates $\beta$-cell survival after islet transplantation of human and mouse islets. Cell Transplantation 22 253-266 (https:// doi.org/10.3727/096368912X647180)

Stokes RA, Cheng K, Lalwani A, Swarbrick MM, Thomas HE, Loudovaris T, Kay TW, Hawthorne WJ, O'connell PJ \& Gunton JE 2017 Transplantation sites for human and murine islets. Diabetologia 60 1961-1971 (https://doi.org/10.1007/s00125-017-4362-8)

Takahashi Y, Sekine K, Kin T, Takebe T \& Taniguchi H 2018 Selfcondensation culture enables vascularization of tissue fragments for efficient therapeutic transplantation. Cell Reports 23 1620-1629 (https://doi.org/10.1016/j.celrep.2018.03.123)

Tang SC, Baeyens L, Shen CN, Peng SJ, Chien HJ, Scheel DW, Chamberlain CE \& German MS 2018 Human pancreatic neuro-insular network in health and fatty infiltration. Diabetologia 61 168-181 (https://doi.org/10.1007/s00125-017-4409-x)

Tang SC, Peng SJ \& Chien HJ 2014 Imaging of the islet neural network. Diabetes, Obesity and Metabolism 16(Supplement 1) 77-86 (https://doi. $\operatorname{org} / 10.1111 /$ dom.12342)

Thorel F, Népote V, Avril I, Kohno K, Desgraz R, Chera S \& Herrera PL 2010 Conversion of adult pancreatic $\alpha$-cells to $\beta$-cells after extreme $\beta$-cell loss. Nature 464 1149-1154 (https://doi.org/10.1038/nature08894)

Van Assche FA, Aerts L \& Prins FD 1978 A morphological study of the endocrine pancreas in human pregnancy. BJOG: an International Journal of Obstetrics \& Gynaecology 85 818-820. (https://doi. org/10.1111/j.1471-0528.1978.tb15835.x)

Van Haeften TW 2002 Early disturbances in insulin secretion in the development of type 2 diabetes mellitus. Molecular and Cellular Endocrinology 197 197-204 (https://doi.org/10.1016/s03037207(02)00267-8)

Wang J, Zhang Y, Cloud C, Duke T, Owczarski S, Mehrotra S, Adams DB, Morgan K, Gilkeson G \& Wang H 2019 Mesenchymal stem cells from chronic pancreatitis patients show comparable potency compared to https://joe.bioscientifica.com

https://doi.org/10.1530/JOE-20-0590
(C) 2021 Society for Endocrinology Published by Bioscientifica Ltd. Printed in Great Britain 
cells from healthy donors. Stem Cells Translational Medicine 8 418-429 (https://doi.org/10.1002/sctm.18-0093)

Wang L, Qing L, Liu H, Liu N, Qiao J, Cui C, He T, Zhao R, Liu F, Yan F, et al. 2017 Mesenchymal stromal cells ameliorate oxidative stressinduced islet endothelium apoptosis and functional impairment via Wnt4- $\beta$-catenin signaling. Stem Cell Research \& Therapy 8188 (https:// doi.org/10.1186/s13287-017-0640-0)

Wei R \& Hong T 2016 Lineage reprogramming: a promising road for pancreatic $\beta$ cell regeneration. Trends in Endocrinology \& Metabolism 27 163-176 (https://doi.org/10.1016/j.tem.2016.01.002)

Wei W, Ehlerding EB, Lan X, Luo QY \& Cai W 2019 Molecular imaging of $\beta$-cells: diabetes and beyond. Advanced Drug Delivery Reviews 139 16-31 (https://doi.org/10.1016/j.addr.2018.06.022)

Williams J, Jacus N, Kavalackal K, Danielson KK, Monson RS, Wang Y \& Oberholzer J 2018 Over ten-year insulin independence following single allogeneic islet transplant without T-cell depleting antibody induction. Islets 10 168-174 (https://doi.org/10.1080/19382014.201 $8.1451281)$

Xiao X, Guo P, Shiota C, Zhang T, Coudriet GM, Fischbach S, Prasadan K, Fusco J, Ramachandran S, Witkowski P, et al. 2018 Endogenous reprogramming of alpha cells into beta cells, induced by viral gene therapy, reverses autoimmune diabetes. Cell Stem Cell 22 78-90.e4 (https://doi.org/10.1016/j.stem.2017.11.020)

Yang H \& Wright JR, Jr 2002 Human $\beta$ cells are exceedingly resistant to streptozotocin in vivo. Endocrinology 143 2491-2495 (https://doi. org/10.1210/endo.143.7.8901)

Yoneda S, Uno S, Iwahashi H, Fujita Y, Yoshikawa A, Kozawa J, Okita K, Takiuchi D, Eguchi H, Nagano H, et al. 2013 Predominance of $\beta$-cell neogenesis rather than replication in humans with an impaired glucose tolerance and newly diagnosed diabetes. Journal of Clinical Endocrinology \& Metabolism 98 2053-2061 (https://doi.org/10.1210/ jc.2012-3832)

Received 25 November 2020

Accepted 5 January 2021

Accepted Manuscript published online 8 January 2021
(C) 2021 Society for Endocrinology Published by Bioscientifica Ltd. 